\title{
INDUSTRY 4.0: THE FUTURE CONCEPTS AND NEW VISIONS OF FACTORY OF THE FUTURE DEVELOPMENT
}

\author{
Dragan Vuksanović, \\ Jelena Ugarak, \\ Davor Korčok
}

Singidunum University, 32 Danijelova Street, Belgrade, Serbia

Correspondence:

Dragan Vuksanović

e-mail:

draganvuksanovic@yahoo.com

\begin{abstract}
:
The aim of this paper is to show the direction of Industry 4.0 future development and the future concepts of the Factory of the Future. The application of new technology based on cyber-physical systems and the Internet leads to significant improvements, such as increase of automation and shorter period between the development of a new product and its market launch.
\end{abstract}

Key words:

industry 4.0, factory of the future (FoF), smart factory, internet of things (IoT), augmented (Virtual) reality.

\section{INTRODUCTION}

The world around us has been changing on a daily basis along with development of human civilization. Therefore, technical and technological developments of production are changing as well. Industry 4.0 is a model that shows how industrial production follows the latest developments and changes over time. Thereby, the man, machine and the production itself constitute the force in one intelligent and independent network.

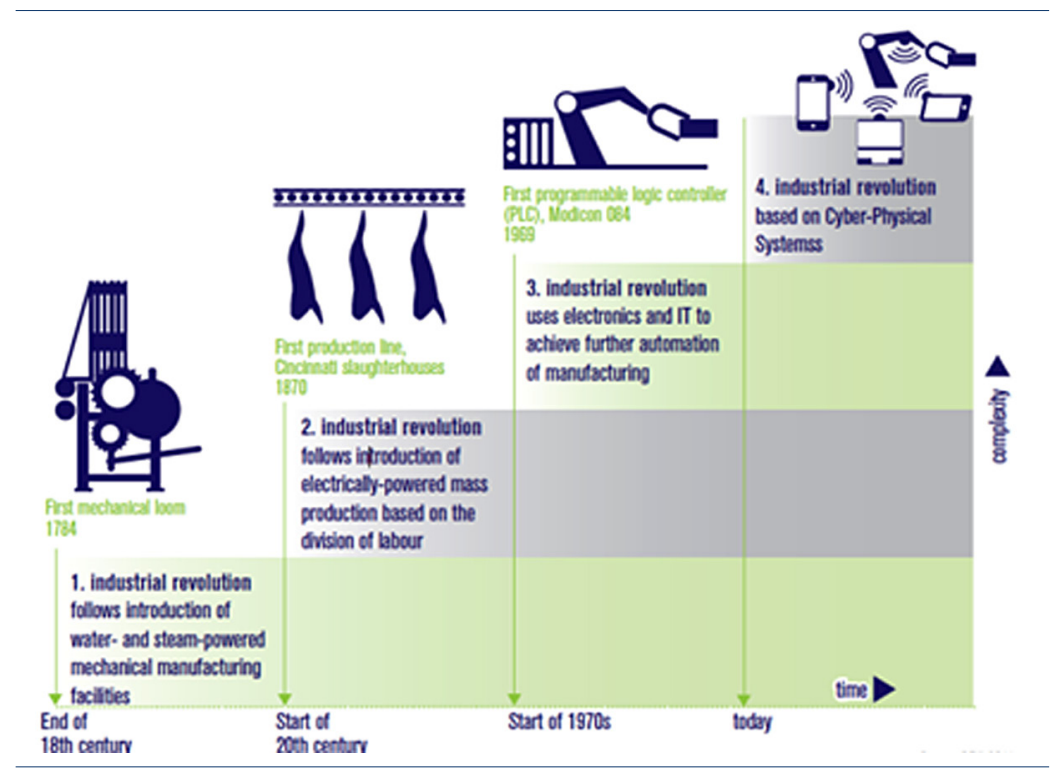

Image 1. The four stages of the industrial revolution [1] 
The term "Industry 4.0" means the smart factory in which smart digital devices are networked and they communicate with raw materials, semi-finished products, products, machines, tools, robots and men. This industry is characterized by flexibility, efficient use of resources and integration of customers and business partners in the business process.

In a networked factory, robots and men are becoming equal partners, having a higher degree of artificial intelligence in relation to the previous generation of robots. The sense sensors that respond to the slightest signal are embedded into the robots, which enables the cooperation between robots and workers.

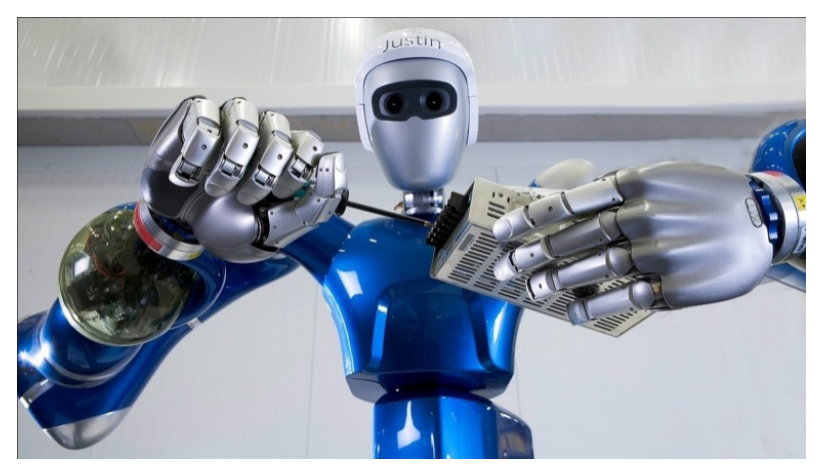

Image 2. An example of future smart robot [2]

The use of digital technology leads to drastic changes in the business models. In order to achieve this, the socalled digital innovation is required. In order to turn a lot of innovations into reality as quickly as possible, the production must become more flexible. Two factors that will help to achieve this goal are hardware and software solutions for the real-time evaluation of data. PLM's digital innovation can be applied to the smart production in a way to influence the entire product life cycle, from $3 \mathrm{D}$ product design and tools for 3D simulation, through automation and system for product control, supply chain management and logistics, till the recycling.

The aim of all these activities is to increase productivity (by drastically shortening the time period between the development of a new product and its delivery to customers in the market for 50\%), efficiency (automation allows for greater flexibility, better quality of products and more efficient production) and energy savings (e.g. while waiting for materials processing, robots can be switched off, if necessary, which saves up to 15 of electricity) to ensure competitiveness in the global market.

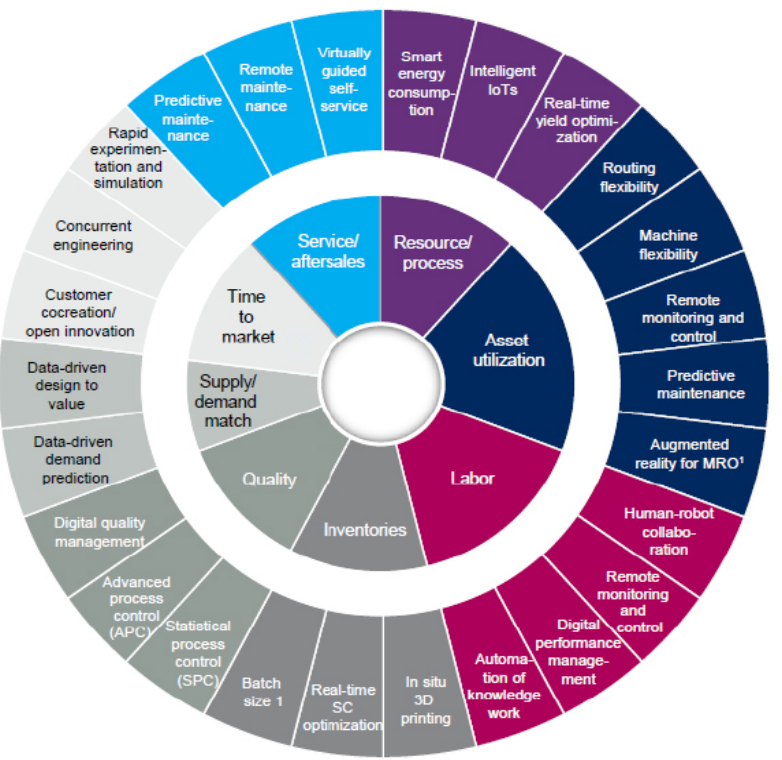

Image 3. The McKinsey Digital Compass maps Industry 4.0 levers to the 8 main value drivers [3]

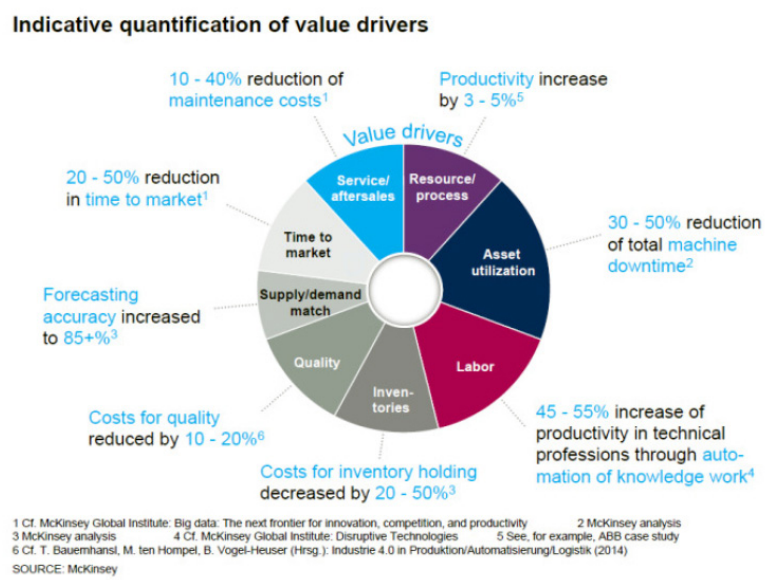

Image 4. Industry 4.0: How to navigate digitalization of manufacture sector, McKinsey [3]

\section{THE ACTION PLAN FOR THE FOURTH EUROPEAN INDUSTRIAL REVOLUTION}

The world's leading producers and the market do not stand still, they are drastically changing and adapting to the new trends every day. During the roundtable of key industry leaders (suppliers of digital technology, manufacturing, chemical and aircraft industry), held on Janu- 
ary 11th 2016, the Commissioner and CEO of revolution "Industry 4.0", Mr. Gunther Oettinger, announced the adoption of an Action Plan for the Fourth European industrial revolution based on four "offensives" [4]:

1. First offensive tells about the necessity for all industrial companies (especially small and medium-sized), from any sector and any part of the EU, to enable an easy access to digital infrastructure and to make innovations.

2. Second offensive stands that the car industry, aviation industry and energetics must take the European leadership in digital industrial railway track.

3. Third offensive is dedicated to the labor force, i.e. to promotion of digital skills across Europe and its regions, at all levels of education and training, in order to prepare workers for the digital revolution and to benefit from it. According to the European Commission for "Industry 4.0" estimation, 150.000 new IT professionals are necessary every year.

4. Fourth offensive tells that countries should adopt common smart regulatory solutions for intelligent industry - how to regulate liability and security of the autonomous systems, ownership and use of industrial data. Digitization of industry by its nature involves cross-border transactions and none of the single Member State is able to find answers to global challenges.

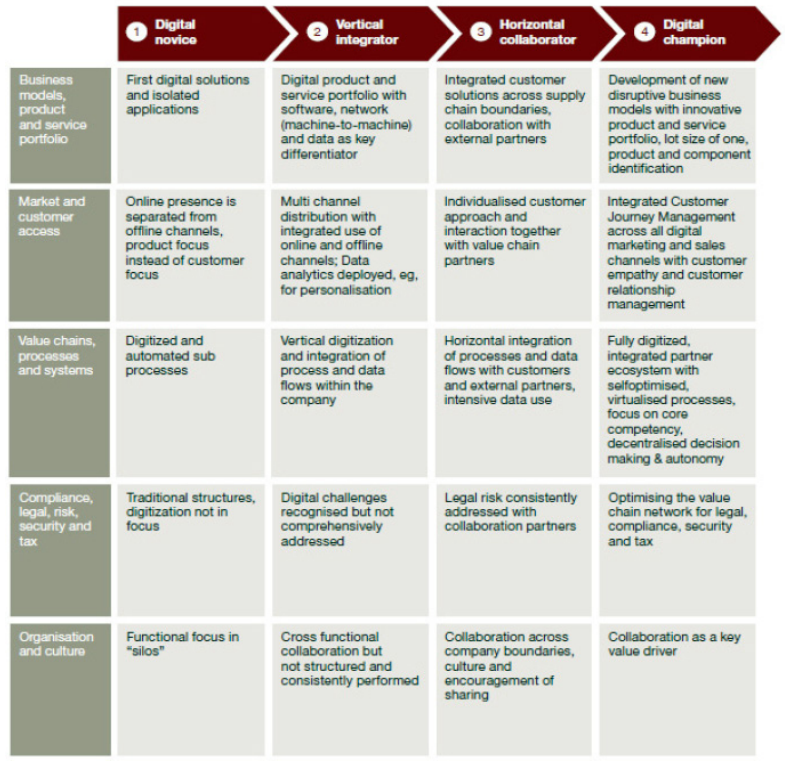

Image 5. Industry 4.0 capabilities develop across five dimensions and four stages [5]

\section{WHAT DOES THIS MEAN FOR SERBIA?}

According to the WEF's survey [3], by 2020 five million workplaces could be lost due to using digitalization in industry of modern countries. Also, it will quickly stop the market demand for the products created by outdated technologies due to the lack of quality and such production would have to be shut down due to high costs and inefficiency. If applied, the digitization will have a significant impact on the industries of developing countries like Serbia. First of all, there must be some change in the "way of thinking", followed by education of all employees, from managers to the production line workers. According to Mrs. Mocan [17], there are four main reasons why developing countries need digitalization:

1. Government inefficiency and poor service delivery;

2. Increasing the digital skills gap between modern and developing industries;

3. Decrease of corruption - A study by Suffolk University found that as the use of information and communication technology by governments increases so corruption decreases;

Digitalization is not the possibility anymore, but the necessity of the modern world.

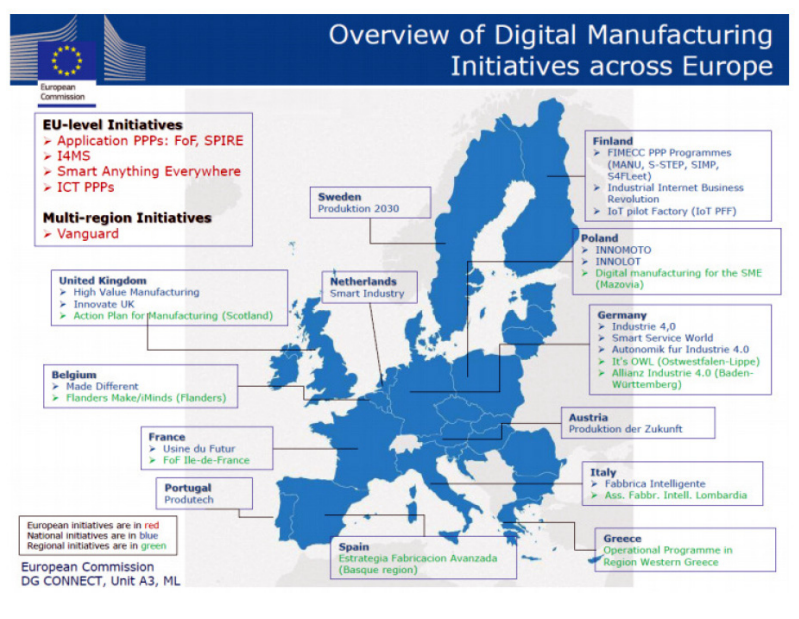

Image 6. Appendix B: Overview of digital Manufacturing Initiatives across Europe [6]

\section{WHAT IS NEEDED FOR THE INTRODUCTION OF INDUSTRY 4.0}

Industry 4.0 includes [8]:

1. Factory 4.0:

- Robots, 
- Autonomous Vehicle (unmanned vehicles),

- 3D Printing / Additive Manufacturing,

- Advanced Manufacturing System,

- Sensors (sensors - data collections),

- Industrial mobile devices (platform),

- Nanotechnology / advanced materials,

2. Cyber Security (Information Security),

3. Software for data processing - Big Data,

4. Logistics 4.0,

5. Mass Customization (a large number of custom),

6. Internet of Things (IOT),

7. High-quality team of employees and experienced team of associates.

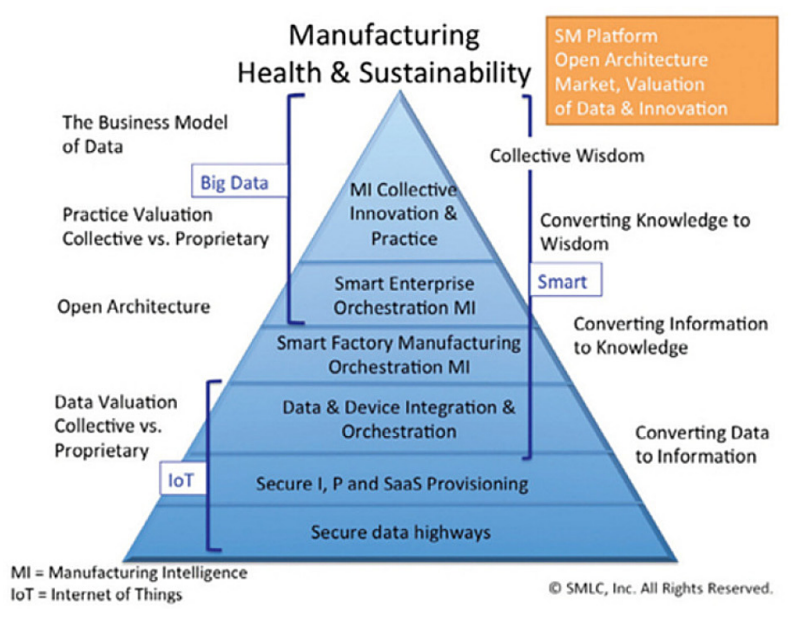

Image 7. Industry 4.0:: Smart Manufacturing's next act [7]

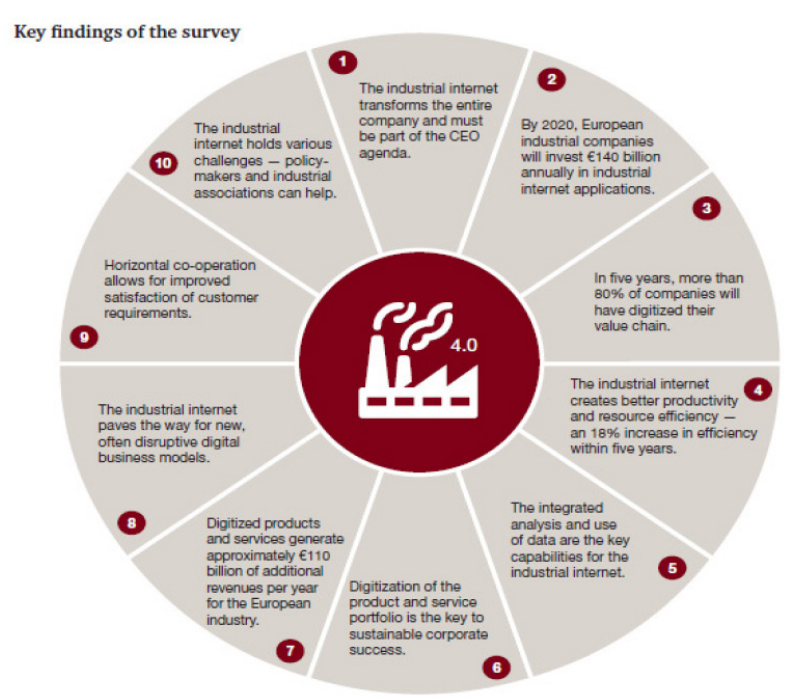

Image 8. Ten key findings of the survey [5]

\section{WHAT MAKES INDUSTRY 4.0 HAPPEN?}

1. Networked systems provide connectivity for local decentralized information processing;

2. Progressive miniaturization allows for small, lowcost and high-performance sensors and actuators;

3. Auto-ID for customized product manufacturing creates unique identification and links to the virtual world;

4. Intelligent field devices using software that allows for the global dynamic distribution of functionality is an integral part of the system integration;

5. Mobile Device Management (MDM): man-machine interfaces for intuitive operation of complex systems without special training.

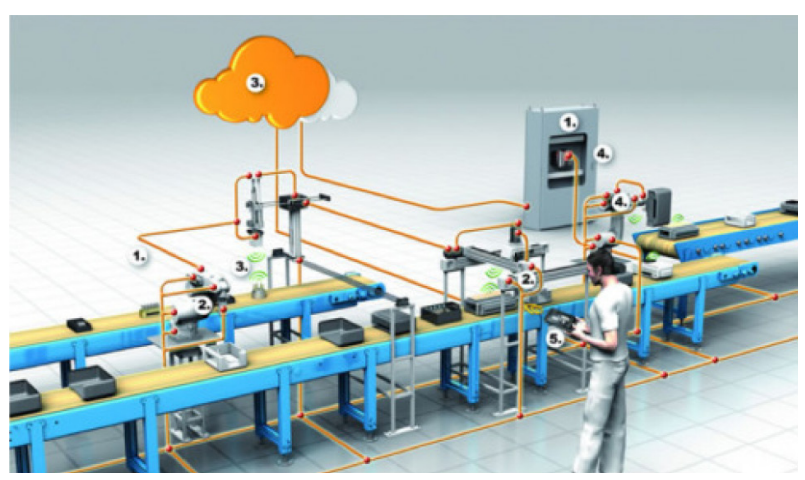

Image 9. The Industry 4.0 factor organizes itself based on a network of communication-capable components [9]

Comparison between the main features of today's factories and factories of the future of Industry 4.0 is shown in Table 1. [10]:

\begin{tabular}{|c|c|c|c|c|c|}
\hline & & \begin{tabular}{|l|} 
Today's Factor \\
\end{tabular} & & \begin{tabular}{|l|} 
Industry 4.0 \\
\end{tabular} & \\
\hline & Data Source & Attributes & Technologies & Attributes & Technologies \\
\hline Component & Sensor & Precision & $\begin{array}{l}\text { Smart Sensors } \\
\text { and Fault } \\
\text { Detection }\end{array}$ & $\begin{array}{l}\text { Self-Aware } \\
\text { Self-Predict }\end{array}$ & $\begin{array}{l}\text { Degradation Monitoring } \\
\text { \& Remaining Useful } \\
\text { Life Prediction }\end{array}$ \\
\hline Machine & Controller & $\begin{array}{l}\begin{array}{l}\text { Productibility \& } \\
\text { Performance }\end{array}\end{array}$ & $\begin{array}{l}\text { Condition-based } \\
\text { Monitoring \& } \\
\text { Diagnostics }\end{array}$ & \begin{tabular}{|l|} 
Self-Aware \\
Self-Predict \\
Sell-Compare
\end{tabular} & $\begin{array}{l}\text { Up Time with Predictive } \\
\text { Health Monitoring }\end{array}$ \\
\hline $\begin{array}{l}\text { Production } \\
\text { systom }\end{array}$ & $\begin{array}{l}\text { Networked } \\
\text { System }\end{array}$ & $\begin{array}{l}\text { Productivity \& } \\
\text { OEE }\end{array}$ & $\begin{array}{l}\text { Lean Operations: } \\
\text { Work and Waste } \\
\text { Reduction }\end{array}$ & \begin{tabular}{|l} 
Self-Configure \\
Self-Maintain \\
Self-Organize
\end{tabular} & Worry-free Productivity \\
\hline
\end{tabular}

Table 1. Comparison of today's factory and an Industry 4.0. factory [10] 


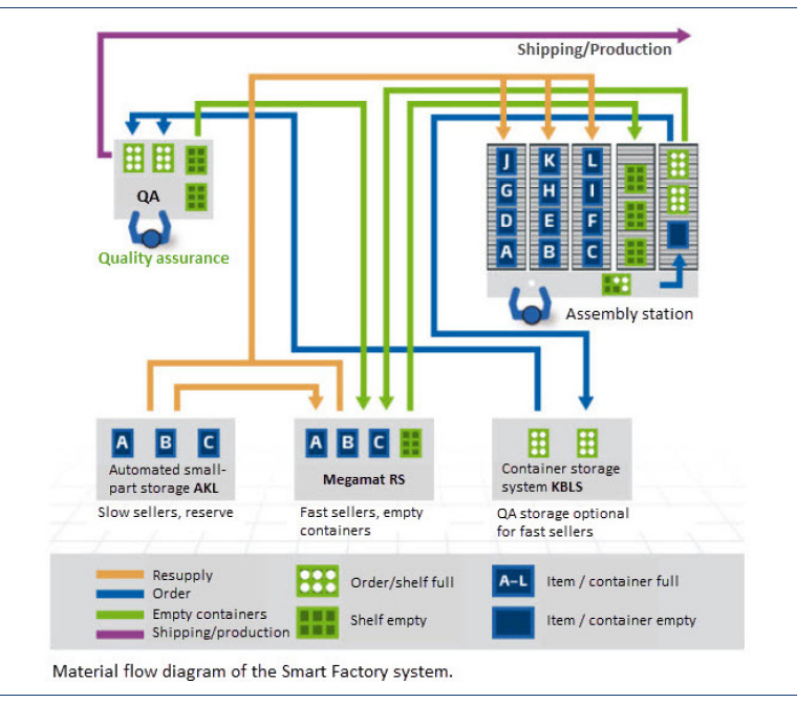

Image 10. Material flow diagram of the Smart factory system [11]

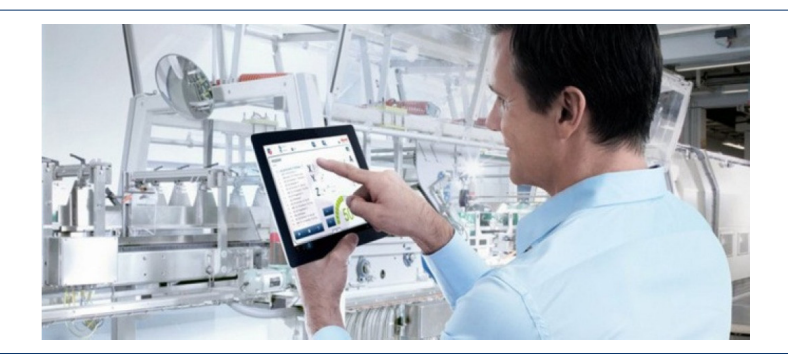

Image 11. The real Industry 4.0 revolution is in business models [12]

People who are employed in companies must be the main driver of changes and innovations related to the introduction and implementation of Industry 4.0. Image 12 shows a comparative overview of the main skills that employees currently have and the skills they will have obtained by 2020 in order to make the Industry 4.0 possible [14].

\section{Top 10 skills}
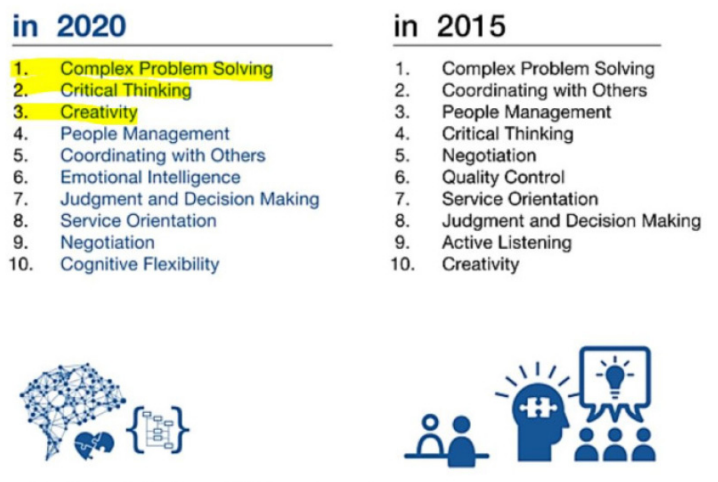

Source: Future of Jobs Report, World Economic Forum

Image 12. Comparison of top 10 skills in 2015 and 2020 [14]

\section{CONCLUSION}

Industry 4.0 is the new industrial revolution of the 21 st century, which enables companies to create "smarter" products and services by reducing costs and increasing efficiency, where the human factor is crucial for the application and the work is based on the existing literature in the area.

Smart Factory makes a solution which, due to the system's automated procedures, uncomplicated setup including simple, need-based installation, and, ultimately, high degree of scalability, can help companies in the manufacturing sector further optimize their processes and significantly boost their internal efficiency.

Five million workplaces could be lost due to digitalization in major industrialized nations by 2020. Also, it will quickly stop the market demand for the products made with outdated technologies due to the lack of quality and such production would have to be shut down due to high costs and inefficiency.

Finally, as Mr. Warren G. Bennis said [16]:

"The factory of the future will have two employees: a human and a dog. The task of the human will be to feed the dog. The dog will have the task to dissuade the human to touch the automated systems. "

\section{REFERENCES}

[1] Industrie 4.0, 31.03.2016. http://www.convertingsystems.com/en/content/42-industrie-40

[2] Robotai gamyklose formuoja ketvirtosios industrijos principus, 31.03.2016. http://robotika.lt/robotaigamyklose-formuoja-ketvirtosios-industrijos-principus/

[3] Industry 4.0. How to navigate digitalization of the manufacturing sector, 31.03.2016.

https://www.mckinsey.de/sites/mck_files/files/ mck_industry_40_report.pdf

[4] "Industry 4.0" ili reindustrijalizacija Evrope, 31.03.2016. http://www.novimagazin.rs/ekonomija/ industry-40-ili-reindustrijalizacija-evrope

[5] Industry 4.0. Opportunities and challenges of the industrial internet, 31.03.2016. http://www.strategyand.pwc.com/media/file/Industry-4-0.pdf

[6] DIRECTORATE GENERAL FOR INTERNAL POLICIES POLICY DEPARTMENT A: ECONOMIC AND SCIENTIFIC POLICY Industry 4.0, 31.03.2016. http://www.europarl.europa.eu/ RegData/etudes/STUD/2016/570007/IPOL_STU (2016)570007_EN.pdf 
[7] Dr. Jay Lee, Behrad Baghery, Hung Ann Kao, Edzel Lapira, Manufacturing leadership journal, February 2015, Industry 4.0 and Manufacturing Transformation, 31.03.2016. http://www.mljournal-digital.com/meleadershipjournal/201502?sea rch_term=Industry\%204.0\&doc_id=-1\&search_ term $=$ Industry\%204.0\&pg $=48 \#$ pg 48

[8] Industry 4.0 Machinery and scope and connotation, 31.03.2016. http://iknow.stpi.narl.org.tw/post/Read. aspx?PostID $=11726$

[9] Industry 4.0 - The Next Industrial Revolution?, 31.03.2016. https://www.eeweb.com/blog/renesas/ industry-4.0-the-next-industrial-revolution

[10] Industry 4.0 and Manufacturing Transformation, Industry 4.0 is regarded as the next generation production framework for the fourth Industrial revolution, 31.03.2016. http://www.mljournal-digital. $\mathrm{com} /$ meleadershipjournal $/ 201502$ ? folio $=36 \& \mathrm{pg}=3$ 8\#pg38

[11] Smart Factory - the Future of Production Logistics, 31.03.2016. http://intralogistics.tips/smart-factoryfuture-production-logistics/

[12] The real Industry 4.0 revolution is in business models, 31.03.2016. http://blog.bosch-si.com/categories/business-models/2014/03/the-real-industry4-0-revolution-is-in-business-models/
[13] Industry 4.0 and Manufacturing Transformation, 31.03.2016. https://www.researchgate.net/publication/271217952_Industry_40_and_Manufacturing_Transformation

[14] Kakšna znanja potrebujejo zaposleni za uspeh v četrti industrijski revoluciji?, 31.03.2016. http:// blog.spica.com/slo/kaksna-znanja-potrebujejo-zaposleni-za-uspeh-v-cetrti-industrijski-revoluciji/

[15] Business, Industry insights Industry 4.0: Everything You Need to Know, 31.03.2016. http://www.cleverism.com/industry-4-0-everything-need-know/

[16] Michael Hattermann, Director Office Brussels, VATM e.V., No doubt about it: Industry 4.0 is needed to keep Germany competitive M2M Summit 2013, Düsseldorf, September 10, 2013, 31.03.2016.

[17] Stela Mocan, Executive Director, E-Government Center, Government of Moldova, "Four reasons developing countries need digital”, 17.03.2015. https://www.weforum.org/agenda/2015/03/4-reasonsdeveloping-countries-need-digital/ 